\title{
Naturally occurring requests in Turkish: A case from an academic context
}

\author{
Uğur Recep Çetinavcı a * (D) \\ a Bursa Uludă̆ University, Faculty of Education, English Language Teaching Department, Bursa 16059, Turkey
}

\begin{tabular}{l|l|l} 
Received 11 November 2019 & Received in revised form 4 June 2020 & Accepted 7 June 2020
\end{tabular}

\section{APA Citation:}

Çetinavcı, U. R. (2020). Naturally occurring requests in Turkish: A case from an academic context. Eurasian Journal of Applied Linguistics, 6(2), 285-311.

Doi: $10.32601 /$ ejal.775809

\begin{abstract}
In terms of their directness and modification strategies, this study investigated how undergraduate speakers of Turkish formulate their naturally occurring requests in an academic context, in which they request things from an academic in his office. After a 4-year data collection period, the researcher analyzed 395 of the requests (hand-recorded as immediate field notes) made to him. The findings on levels of directness revealed that the strongest tendency is towards conventionally indirect strategies, while the female tendency towards them is even clearer. The dominance of conventional indirectness is in parallel also with the degree of imposition of the requests. 'Zero marking' is what dominates the findings on internal modification strategies, while some preferences, such as unfinished sentences, could suggest language or context-specific results. In light of these descriptive findings on a part of everyday language in academia, the study could in practical terms help learners and teachers of Turkish and Turkish learners/teachers of English or any other language as well. Moreover, it could contribute to the efforts towards handling the methodological concerns in pragmatics research about the extent to which elicited data can represent what people actually say in natural conversation.
\end{abstract}

(C) 2020 EJAL \& the Authors. Published by Eurasian Journal of Applied Linguistics (EJAL). This is an open-access article distributed under the terms and conditions of the Creative Commons Attribution license (CC BY-NC-ND) (http://creativecommons.org/licenses/by-nc-nd/4.0/).

Keywords: Pragmatics; requests; naturally occurring data; field notes; directness; modification

\section{Introduction}

\subsection{Research problem}

Pragmatics is the study of 'language in use', and within pragmatics, the pursuit of validity enhancement in speech acts research (on requests, refusals, apologies, compliments etc.) has long seen queries about the appropriacy of data collection instruments. In this respect, while naturally occurring speech acts are the unanimously favored data, issues such as recording them under effectively-controlled variables have prioritized 'elicited data' through DCTs (discourse-completion tests) and role-plays,

\footnotetext{
* Corresponding author. Tel.: +0-224-294-2260

E-mail address: cetinavci@uludag.edu.tr

http://dx.doi.org/10.32601/ejal.775809
} 
despite their questioned ability to approximate natural interaction. Accordingly, empirical studies based exclusively on naturalistic data are in the minority (Economidou-Kogetsidis, 2013). This scarcity is even more self-evident with respect to the Turkish language. Huls's (1988) study can be mentioned as one focused on the natural request contexts in a Turkish family settled in the Netherlands. Aksan and Mersinli (2015) added a corpus-based research, in which they retrieved requestives from a spoken subcorpus in the Turkish National Corpus, as a reasonable alternative to elicited data with its great potential for authenticity (Leech, 2011).

In this regard, given that few studies on requests have relied exclusively on authentic data and very few have done that to investigate the requestives in contextualized Turkish, this study aims to examine how Turkish-speaking university students request things from academics. The natural context here is when a student spontaneously comes to the office of an academic for a request. The examination is with respect to the dependent variables of (a) degrees of directness and (b) phrasal/lexical and syntactic modification in relation to the independent variables of gender and different request situations.

In line with this scope, the following section reviews the pertinent literature on the features of naturalistic data and sociopragmatic variables that affect requesting behavior in terms of directness and internal modification, thus (im)politeness.

\subsection{Literature Review}

\subsubsection{Naturally occurring data}

As DCTs and role-plays tend to document ideal situations rather than real ones (Golato, 2005), optimal data for speech act analysis would comprise a large number of carefully recorded observations in natural situations when the representative subjects are unaware of the observation (Hinkel, 1997). With such motivation, naturalistic data in pragmatics research are collected from authentic speech events with audio-recording, video-recording or field notes (Economidou-Kogetsidis, 2013). Among these, audio/video recording is favored, for field notes rely solely on the note-taker's memory, thus failing to capture content such as paralinguistic features (Kasper \& Rose, 2002). However, as mentioned before, naturally occurring data raise some practicality issues such as being able to collect sufficient quantities of the target pragmatic feature, control the sociopragmatic variables (Yuan, 2001) and gather data systematically from clearlydefined populations (Beebe \& Cummings, 1996). These issues could prevent naturalistic data from being accurately ethnographic and curb the generalizability of findings (Economidou-Kogetsidis, 2013). The following sections describe the efforts in the present study to tackle such issues, which is important as the literature reports that sociopragmatic variables can affect the request performance of any population (BlumKulka, 1987; Jalilifar, 2009; Martı, 2006). 


\subsubsection{Sociopragmatic variables of request behavior}

Among others such as 'degree of interlocutor familiarity', gender, a common variable also investigated in this study, is a subject matter of classic theories suggesting that females are often more polite in language use (Aitchison, 1992; Güney, 2015; Holmes, 1995; Lakoff, 1975; Shams \& Afghari, 2011). As specific to requests by Turkishspeaking undergraduates, Karagöz and İşisağ (2019) report that their female participants acted more politely and appropriately, in conformity with those theories. This is a notion that had already been corroborated as prominent in Turkish culture, where women's language sounds distant from power until they can become breadwinners (Zeyrek, 2001), while male speech has some conspicuous features of selfassertion (Hayasi, 1998), and keeping conversational distance with men is a female sensitivity (Bayyurt \& Bayraktaroğlu, 2001).

The other independent variable covered in this study is different request situations that harbor varying degrees of imposition. We know that language users tend to use more polite means of requesting when the perceived rank of imposition is high (BlumKulka, 1987; Jalilifar, 2009), which is also verified by Martı (2006) with regard to Turkish with a situation-specific perspective. In terms of the current study, the imposition was lower when, for example, the subjects asked the researcher to sign an official document, which is already a statutory responsibility for him. However, the imposition must have been perceived as higher when the participants asked to use his office PC, which would normally be considered beyond the call of duty.

The degree of directness, which is affected by such variables as those mentioned above and affects levels of politeness accordingly, covers three main strategies with their embedded substrategies (Blum-Kulka, House, \& Kasper, 1989; EconomidouKogetsidis, 2013) (see Appendix A). Below, they are defined and exemplified with extracts from the data set of this study:

(1) Most direct strategies: This level is realized via requests based on strategies like ellipsis, where some of the words that make a complete question are omitted (e.g., 'Hocam bi imza?' = 'Teacher a signature?').

(2) Conventionally indirect strategies: This level concerns strategies that realize the act by reference to contextual preconditions necessary for its performance, as conventionalized in a given language with some structures (e.g., 'Sunumumuz için hoparlörlerinizi alabilir miyiz bi 15 dakka?' = 'Can/Could we take (borrow) your loudspeakers for just 15 minutes for our presentation?').

(3) Non-conventionally indirect strategies (hints): Not conventionalized with structures like 'Can I/we' etc., this category covers strategies that would require the hearer to elicit what is implied with the act (e.g., 'Bizim kısa bi çevirimiz var da.' = 'We have a short translation, but...').

Internal modification, the other dependent predictor of politeness in relation to the variables of gender and different request situations, refers to how the requests are modified through the use of some elements in a way that is not essential for the utterance to be potentially understood as a request (Blum-Kulka, 1989). They are used 
at lexical/phrasal or syntactic level, and might act either as downgraders meant to soften the request (e.g., '2 saniyeliğine marker alabilir miyim?' = 'Can I take [borrow] a board marker for two seconds?'), or as upgraders meant to intensify the coerciveness of a request (e.g., 'Acilen bi şeye bakabilir miyim otomasyonda?' = 'Can I urgently look at something on the student information system?') (See Appendices B and C).

A broader look at the literature suggests that languages can differ in terms of interplays between the abovementioned variables and requestive directness and modification, thus politeness strategies. In this regard, scholars such as Kasper (1992) have underscored the probable 'negative pragmatic transfer' effects between mother tongues and second/foreign languages being learnt, for a speaker in a particular second or foreign language context might just translate and transfer a linguistic device perceived as 'polite' in his/her own language into his/her request formulated in the target language, which could turn out to be 'impolite', or even rude. Within this perspective, the descriptive findings of this study are meant to serve as a reference point for learners/teachers of Turkish about the pragmatics of the language and also Turkish learners/teachers of any other language by giving clues on 'negative transfer' likely to be sourced from Turkish.

Another segment of the literature to refer to the significance of this study would be in terms of its probable contributions to research methodology. As mentioned before, for data collection, speech act studies have typically used elicited data and natural data. The latter is the much less frequent method, and the extent to which elicited data can represent what people actually say (González-Cruz, 2014) is questioned (Billmyer \& Varghese, 2000; Economidou-Kogetsidis, 2013; Félix-Brasdefer, 2010). Sound arguments can be developed through comparative studies examining pragmatic features with both methods. In this regard, as Economidou-Kogetsidis (2013) did when comparing DCT requests with naturally occurring telephone requests in a call center, there is always the need for the natural data part in that duality. Accordingly, the present study aims to provide a good number of naturally occurring pragmalinguistic features in Turkish in a specific situation, which can serve as a comparison baseline with studies using DCT request situations that are identical to the ones in this study.

\section{Method}

\subsection{Setting}

The setting, and the spontaneous encounters that took place in it, have some identifying characteristics. The office, at a mid-size university in the north-western part of Turkey, housed the researcher with an age nearer to the students' than the vast majority of the other academics and a position just above the bottom of the hierarchical organization there. The office was in a teacher-training department and functioned also as the room where the staff kept the common laptop, a portable projector and a substitute device to switch on the built-in projectors in the classrooms for the frequent student presentations mostly accompanied by a whiteboard and several paper 
materials, which occasionally created some unanticipated but immediate needs for use of additional materials/tools like stationery supplies that could possibly be found in a teacher's office.

There was still, however, a certain degree of social/organizational distance between the interlocutors, for the hearer was, after all, an academic and the requesters were undergraduates. All the analyzed speech events contained the speech act of requests, where a student knocks on the door, opens it after a brief pause, and makes his/her request for the academic there to do something. After salutation, followed very rarely by a talk irrelevant to the request, the student makes his/her request, which can be viewed as an opening request as it opens the exchange of the speaker's request-making and the hearer's response (Economidou-Kogetsidis, 2013) in the regularity of turntaking.

We should note that encounters with the abovementioned features are culturally tolerated (in relative terms). This has been echoed in studies on institutional culture in Turkish higher education. Below is exemplary feedback by an Erasmus student attending different departments of a Turkish university (Boyac1, 2011, p. 277), the core content of which is also verified in Zeyrek (2001):

"The faculty members are congenial to the students. They always try to answer their questions. They devote time for them out of the classroom. [...] There is a more informal communication with students here."

\subsection{Data and subjects}

The data comprise 395 requests in 395 encounters over a span of 4 years, which gives the design a feature of longitudinal pragmatics research (Taguchi, 2018). The subjects, aged mostly between 18 and 22, are Turkish speakers as L1 and English language teacher trainees. The requests occurred in 26 different situations. The four most frequent are when the request target was a material/tool, having an official document signed, using the office $\mathrm{PC}$, and the temporary right to attend a lesson in a different class from the regular one. As in Economidou-Kogetsidis (2013), to alleviate the reliance on the researcher's memory and avoid data damage, only the head acts (the minimal units to realize requests) were made the focal point to be recorded as immediate field notes.

277 requests belong to females and 118 to males. For homogeneity, the requests included were only those made directly to the researcher when he was seated with his hands on his keyboard or mouse. This was concerned with giving a similar image to the interlocutors and proximity to the notebook allocated for data recording.

None of the students was aware that his/her request was going to be recorded after the visit (Hinkel, 1997). The aim was to keep the utterances truly natural. Given this rigor for naturalness, it was not possible to query them for additional background information. It was not possible either to detect how many of the students had more than one request encounter during that 4 -year period. Thus, a low number of them 
would appear in the database more than once. Under these circumstances, what was done to collect maximum natural data in a consistent manner was to record after each visit the requester's gender and some other variables like the program year s/he was studying if the researcher knew that for certain (beyond the scope of the current study). The pages of the notebook allocated for the purpose had been uniformly organized with boxes under titles jotted down as 'Date', 'Gender', etc. and spaces to write as much of each conversation as possible. It was often impossible to record the speech events together with the (supra)segmental details and follow-ups since the researcher had chosen the head acts as the feature to commit to memory in those instances of 'pop-in' requests. More details would have been absolutely ideal with video-recording, thanks to which features like pauses, smiles, etc. can be analyzed as interactional resources accompanying linguistic material, thus reflecting the conversation analytic view of discursive pragmatics (Kasper, 2006). That extent had not been given full consent, however. Throughout the study period, in the customary plenary meetings with the freshmen of the department at the beginning of each academic year, all the students were informed that longitudinal studies could be conducted on aspects of classroom or office interactions in Turkish or English, and that the utterances in naturally occurring exchanges may be covered as research data. It was explained that their consent would not affect their performance in their course grades, and that their names would be kept anonymous. Full consent related to office interactions was given for field notes only. Under these circumstances, whenever the researcher could not make absolutely sure that any 'head act' had been recorded in its entirety, a note was taken to exclude it from the scope of this study. In this regard, a total of 508 student requests were recorded fully or in fragments, and analyses were done on 395 of them for the present study.

All the procedural details were finalized in light of the experiences on the data acquisition process and coding challenges learnt through a piloting phase, where data recording and coding had been rehearsed for about two months using the main study's devices, schemes and practices documented in this section, the following section and the appendices.

\subsection{Data analysis and coding}

The requests were analyzed within particular frameworks. For the main strategies of directness, the coding categories in Economidou-Kogetsidis (2013) adapted from Blum-Kulka et al. (1989) were used (see Appendix A). To analyze and classify the internal modification devices, the schemes in Economidou-Kogetsidis (2013) were used (see Appendices B and C), which themselves had been refined in consideration of several other studies. As done by Flöck (2016), some other categories not found in those schemes were introduced into the analyses, about which more details are given further in the text. For statistical analyses, when the directness or modification preferences were analyzed as a set of categorical data from all the participants as a single population, chi-square goodness-of-fit tests were employed. However, when the analyses were on determining whether other categorical data like gender were related to the preferences, chi-square tests for independence were conducted. 
As in Ren (2019), 20\% of the requests (79 out of 395) were coded for interrater reliability by a colleague, who had studied and published on pragmatics and has long been a receiver of student requests in a context similar to the one in the present study. This took place after an orientation period with the researcher. The coding schemes were negotiated then, and the requests in the piloting phase were used for coding practice. Those 79 requests, randomly selected by a software program, contained 141 acts of coding as to the head act strategies and modification devices. On her own, the colleague coded 138 of them in the way the researcher had done, which gives an agreement rate of $97.87 \%$. The discrepancies were resolved by discussion, and all of the data were included for analysis.

\section{Results}

\subsection{Degrees of requestive directness}

As seen in Table 1, which gives the overall findings, 7.59\% of the requests were made with the most direct strategies while $52.40 \%$ and $40 \%$ of the requests contained conventional indirectness and hints, respectively.

Table 1. Request strategies by level of directness and use frequencies

\begin{tabular}{|c|c|c|}
\hline Level of Directness & $\%$ & Examples \\
\hline Most direct & $7.59 \%(30 / 395)$ & \\
\hline Imperative & $3.33 \%(1 / 30)$ & İmzalayın lütfen. (Sign [it] please.) \\
\hline Ellipsis & $10 \%(3 / 30)$ & Kalem? (A pen?) \\
\hline Performative & $30 \%(9 / 30)$ & $\begin{array}{l}\text { Bunu imzalatmaya geldim. (I have come } \\
\text { to get this signed.) }\end{array}$ \\
\hline Want statements & $23.33 \%(7 / 30)$ & $\begin{array}{l}\text { Hoparlör isteyecektik. (We were going to } \\
\text { want/ask for loudspeakers.) }\end{array}$ \\
\hline Need statements & $33.33 \%(10 / 30)$ & $\begin{array}{l}\text { Brown'un kitabı lazım bana. (I need } \\
\text { Brown's book.) }\end{array}$ \\
\hline Conventionally indirect & $52.40 \%(207 / 395)$ & \\
\hline Suggestory formulae & $0.48 \%(1 / 207)$ & Siz imzalasanız? (What if you sign [it]?) \\
\hline Query preparatory & $99.51 \%(206 / 207)$ & $\begin{array}{l}\text { Soruları yazıp size versek cevaplar } \\
\text { mısınız? (Would you answer the } \\
\text { questions if we wrote [them] down and } \\
\text { gave (them to) you?) }\end{array}$ \\
\hline Non-conventionally indirect & $40 \%(158 / 395)$ & \\
\hline Strong hints & $93.67 \%(148 / 158)$ & $\begin{array}{l}\text { Tahta kaleminiz var mi? (Do you have a } \\
\text { board marker?) }\end{array}$ \\
\hline Mild hints & $6.32 \%(10 / 158)$ & $\begin{array}{l}\text { Ben şimdi konuştum ... hocayla da, } \\
\text { yoldaymış. Bunu (dosyayı) buraya } \\
\text { bırakmamı söyledi. (I have just talked to } \\
\ldots \text { teacher, she is on the road. She has told } \\
\text { me to leave this [the file] here.) }\end{array}$ \\
\hline
\end{tabular}

A closer look at Table 1 suggests that when the subjects preferred directness, they mostly avoided 'Imperative' and 'Ellipsis'. 'Need statements' were prevalent in onethird of cases. Another typical example is given below: 
1] 'Bir kaleme ihtiyacım var hocam ama...' = 'I need a pen, teacher, but...'

The key finding here is that $52.4 \%$ of the requests contain conventionally indirect strategies, followed by non-conventional ones (40\%). The chi-square goodness-of-fit test confirmed that there were statistically significant differences in the preference for level of directness, with fewer people preferring the most direct strategies $(\mathrm{n}=30)$ compared to either of the other two $\left[\mathrm{x}^{2}(2)=126.8, \mathrm{p}<0.01\right]$.

All but one of the conventionally indirect strategies were based on the 'query preparatory' substrategy, as in examples 2 and 3 below:

2] '...Bi örnek (referans mektubu) varsa alabilir miyim flaşa?' = '...Can I get a

(reference letter) sample into my flash (drive) if there is/you have one?'

3] '...Ben dün dersinize giremedim de, bugün girebilir miyim şimdiki dersinize?' =

'...I couldn't attend your class yesterday; may/can I attend now your class today?'

Non-conventionally indirect strategies, all but ten of which were strong hints, follow conventional indirectness with $40 \%$. Examples 4 and 5 illustrate respectively the typical strong and mild hints:

4] 'Sizde böyle 4 skill'e de hitap eden bir kitap var mı?' = 'Do you have a book that addresses all the four skills?'

5] 'Öğrenci: Merhaba hocam. Sinavları okudunuz mu?

Araştırmacı: Okuyorum.

Öğrenci: Ne zaman biter? Size göre sıkıntılı bir durumum var da...'

$=$

'The student: Hi teacher. Have you finished marking the exams?

The researcher: I am marking (them).

The student: When will you finish? I'm in an awkward situation in relation to you $($ r exam $) .. . '$

In example 5, the student wanted to know if she would have to sit the retake exam, which meant staying in the city of the university for an additional week. Accordingly, she was trying to make the researcher announce her final exam score earlier than the general announcement, hoping that her paper had been marked. On occasions like this, when a mild hint seemed to have been made, the researcher asked (a) confirmation question(s) after the student took his/her conversational turn. Concerning example 5 for instance, the question was 'You want me to tell you your score, thinking that your paper might be among the marked ones, right?' It was only after the students had verified their intentions that such utterances were recorded as mild hints. These occasions amount to $2.5 \%$ of the whole data set (10/395).

Comparisons according to gender yielded interesting results in terms of differences in directness, as displayed in Table 2: 
Table 2. Level of directness according to gender

\begin{tabular}{|c|c|c|c|}
\hline Level of Directness & $\begin{array}{l}\text { Female } \\
(\mathrm{N}=277)\end{array}$ & $\begin{array}{l}\text { Male } \\
(\mathrm{N}=118)\end{array}$ & Examples \\
\hline Most direct & $\begin{array}{l}6.85 \% \\
(19 / 227)\end{array}$ & $\begin{array}{l}9.32 \% \\
(11 / 118)\end{array}$ & \\
\hline Imperative & $\begin{array}{l}5.26 \% \\
(1 / 19)\end{array}$ & 0 & İmzalayın lütfen. (Sign [it] please.) \\
\hline Ellipsis & $10.52 \%(2 / 19)$ & $9.09 \%(1 / 11)$ & $\begin{array}{l}\text { Levent hocanin pointer's? (Levent } \\
\text { teacher's [laser] pointer?) }\end{array}$ \\
\hline Performative & $21.05 \%(4 / 19)$ & $\begin{array}{l}45.45 \% \\
(5 / 11)\end{array}$ & $\begin{array}{l}\text { Tepegözü alacaktım. (I was going } \\
\text { to get the overhead projector.) }\end{array}$ \\
\hline Want statements & $21.05 \%(4 / 19)$ & $\begin{array}{l}27.27 \% \\
(3 / 11)\end{array}$ & $\begin{array}{l}\text { Makas isteyecektim. (I was going to } \\
\text { ask for/want scissors.) }\end{array}$ \\
\hline Need statements & $42.10 \%(8 / 19)$ & $\begin{array}{l}18.18 \% \\
(2 / 11)\end{array}$ & $\begin{array}{l}\text { İmzaniz gerekiyor da... (Your } \\
\text { signature is needed, but ...) }\end{array}$ \\
\hline Conventionally indirect & $\begin{array}{l}57.76 \% \\
(160 / 277)\end{array}$ & $\begin{array}{l}39.83 \% \\
(47 / 118)\end{array}$ & \\
\hline Suggestory formulae & $0.62 \%(1 / 160)$ & 0 & $\begin{array}{l}\text { Siz imzalasanı?? (What if you sign } \\
\text { [it]?) }\end{array}$ \\
\hline Query preparatory & $\begin{array}{l}99.37 \% \\
(159 / 160)\end{array}$ & $100 \%(47 / 47)$ & $\begin{array}{l}\text { Çeviri kağıtlarına bakabilir } \\
\text { miyim? (Can I look at the translation } \\
\text { [exam] papers?) }\end{array}$ \\
\hline $\begin{array}{l}\text { Non-conventionally indirect } \\
\text { (hints) }\end{array}$ & $\begin{array}{l}35.37 \% \\
(98 / 277)\end{array}$ & $\begin{array}{l}50.84 \% \\
(60 / 118)\end{array}$ & $\begin{array}{l}\text { Ben ilişik kesmek için } \\
\text { danışmanımı aradım ama } \\
\text { bulamadım. (I looked for my academic } \\
\text { advisor for exmatriculation but couldn't } \\
\text { find him.) }\end{array}$ \\
\hline
\end{tabular}

As reflected in Table 2, females used the conventionally indirect strategies more frequently while males preferred hints more strongly. The chi-square test for independence confirmed the statistically significant association between gender and requestive directness $\left[x^{2}(2)=10.6, \mathrm{p}<.01\right]$.

As previously mentioned, 395 requests in 26 different situations were examined, including fragments. 83 were in a situation where the researcher was asked to sign a document, 217 were for a material, 10 were for briefly using the researcher's PC, 32 were made to attend a lesson in a different class from the regular one, and 53 occurred in 22 other situations with minor frequencies of fewer than 10 (such as asking the researcher to write a recommendation letter, do a survey etc.). The findings are in Table 3.

Table 3 shows that all the students preferred conventional indirectness for a brief use of the office PC and the one-week exclusive right to attend a lesson in a different class. They favored conventionality over non-conventional indirectness with respect also to the situations labelled 'Others' (Chi-square results: $\left.\left[x^{2}(2)=49.05, \mathrm{p}<.01\right]\right)$. This is also valid in terms of the 'Document Signing' situation $\left[x^{2}(2)=24.8, \mathrm{p}<.01\right]$. Nonetheless, the findings on 'Requesting a Material' were in the opposite direction to the ones hitherto documented: the participants preferred non-conventionality to a significant extent $\left[x^{2}(2)=72.3, \mathrm{p}<.01\right]$. 
Table 3. Directness according to the request situations

\begin{tabular}{llllll}
\hline Level of directness & Situations & & \\
& $\begin{array}{l}\text { Signing } \\
(\mathrm{N}=83)\end{array}$ & $\begin{array}{l}\text { Material } \\
(\mathrm{N}=217)\end{array}$ & $\begin{array}{l}\text { PC use } \\
(\mathrm{N}=10)\end{array}$ & $\begin{array}{l}\text { Attending } \\
\text { a Different Class } \\
(\mathrm{N}=32)\end{array}$ & $\begin{array}{l}\text { Others } \\
(\mathrm{N}=53)\end{array}$ \\
\hline Most Direct & $12.04 \%$ & $8.75 \%$ & 0 & 0 & $1.88 \%$ \\
& $(10 / 83)$ & $(19 / 217)$ & & & $(1 / 53)$ \\
\hline Imperative & 1 & 0 & 0 & 0 & 0 \\
Ellipsis & 0 & 3 & 0 & 0 & 0 \\
Performative & 5 & 3 & 0 & 0 & 1 \\
Want statements & 2 & 5 & 0 & 0 & 0 \\
Need statements & 2 & 8 & 0 & 0 & 0 \\
\hline Conventionally indirect & $56.62 \%$ & $35.48 \%$ & $100 \%$ & $100 \%$ & $77.35 \%$ \\
& $(47 / 83)$ & $(77 / 217)$ & $(10 / 10)$ & $(32 / 32)$ & $(41 / 53)$ \\
\hline Suggestory formulae & 1 & 0 & 0 & 0 & 0 \\
Query preparatory & 46 & 77 & 10 & 32 & 41 \\
\hline Non-conventionally & $31.32 \%$ & $55.76 \%$ & 0 & 0 & $20.75 \%$ \\
indirect & $(26 / 83)$ & $(121 / 217)$ & 0 & 0 & $(11 / 53)$ \\
\hline
\end{tabular}

Apart from the above, an additional qualitative look revealed that among the 23 supportive moves external to the head act (Faerch \& Kasper, 1989), based specifically on an imposition minimizer to reduce the impact by stating that the request is only relevant under certain conditions (Blum-Kulka et al., 1989: 288), thus often involving a conditional clause, 16 accompanied the occasions of query preparatory substrategy ('...miyim/miyiz?' = 'Can/Could/May I/we ...?') to ask for a material. Below is an example:

6] 'Bölümün laptopunu alabilir miyiz eğer burdaysa?' = 'Can we take (borrow) the laptop of the department if it is here?

\subsection{Internal modification of the requests}

Table 4 presents the overall findings on how the requests were modified with lexical/phrasal devices. 
Table 4. Internal modification with lexical/phrasal devices (in 395 requests and among 91 uses) *

\begin{tabular}{|c|c|c|c|}
\hline Devices & $\begin{array}{l}\text { In the } \\
\text { requests }\end{array}$ & $\begin{array}{l}\text { Among } \\
\text { themselves }\end{array}$ & Examples \\
\hline Zero Marking & $\begin{array}{l}78.7 \% \\
(311 / 395)\end{array}$ & & \\
\hline 'I beg you'** & $\begin{array}{l}0.3 \% \\
(1 / 395)\end{array}$ & $1.09 \%(1 / 91)$ & Nolur. (I beg you.) \\
\hline Consultative Devices & $\begin{array}{l}4.8 \% \\
(19 / 395)\end{array}$ & $\begin{array}{l}20.87 \% \\
(19 / 91)\end{array}$ & $\begin{array}{l}\text { Sinav sonucu açıklanmış. Paketim yok. } \\
\text { Baksanız olur mu? (The exam results have } \\
\text { been announced. I don't have an Internet } \\
\text { package. Is it OK if you/Would it be OK if } \\
\text { you look at it? [He asks the researcher to look } \\
\text { at the exam result on the office PC through } \\
\text { the Student Affairs Information System as he } \\
\text { does not have Internet connectivity on his } \\
\text { mobile phone] }\end{array}$ \\
\hline Downtoners & $\begin{array}{l}0.3 \% \\
(1 / 395)\end{array}$ & $1.09 \%(1 / 91)$ & $\begin{array}{l}\text { Müsaadenizle ben } 18.45 \text { gibi çıkabilir } \\
\text { miyim? (Can I leave at about } 18.45 \text { with your } \\
\text { permission?) }\end{array}$ \\
\hline Hedges & $\begin{array}{l}3.5 \% \\
(14 / 395)\end{array}$ & $\begin{array}{l}15.38 \% \\
(14 / 91)\end{array}$ & $\begin{array}{l}\text { 2 saniyeliğine marker alabilir miyim? (Can I } \\
\text { take [borrow] a marker for two seconds?) }\end{array}$ \\
\hline Subjectivizers & $\begin{array}{l}12.7 \% \\
(50 / 395)\end{array}$ & $\begin{array}{l}54.94 \% \\
(50 / 91)\end{array}$ & $\begin{array}{l}\text { Daksiliniz var mı acaba? (Do you have } \\
\text { correction fluid I wonder?) }\end{array}$ \\
\hline Appealers & $\begin{array}{l}0.5 \% \\
(2 / 395)\end{array}$ & $2.19 \%(2 / 91)$ & $\begin{array}{l}\text { Derse misafir kabul ediyorsunuz di mi? (You } \\
\text { accept guests into your classroom, don't } \\
\text { you/right?) }\end{array}$ \\
\hline Time Intensifiers & $\begin{array}{l}0.3 \% \\
(1 / 395)\end{array}$ & $1.09 \%(1 / 91)$ & $\begin{array}{l}\text { Hemen bi şeye bakabilir miyim } \\
\text { otomasyonda? (Can I look right away at } \\
\text { something on the information system?) }\end{array}$ \\
\hline $\begin{array}{l}\text { Possibility } \\
\text { Seekers }\end{array}$ & $\begin{array}{l}0.8 \% \\
(3 / 395)\end{array}$ & $3.29 \%(3 / 91)$ & $\begin{array}{l}\text { Cevap anahtarına bakma şansımız var mi? } \\
\text { (Do/Would we have the chance to see the answer } \\
\text { key?) }\end{array}$ \\
\hline
\end{tabular}

* The number of the modifiers is not equal to that of the requests as more than one modifier was used in some cases.

** In the adopted coding schemes from the literature, this slot harbors the marker 'please'. Nonetheless, there was no 'lütfen' = 'please' in the data set of this study but one 'nolur' = 'I beg you', which has been considered a performative prefix as an illocutionary force indicating device (Leech and Thomas, 1990) that can signal the 'asking' force with 'please' (Huddleston and Pullum, 2002).

On the one hand, what stands out in Table 4 is the fact that there was no marking in most of the requests. On the other hand, preferred in almost $55 \%$ of the 91 device uses, 'subjectivizers' turned out to be the dominant one among all. Chi-square tests attested to the significant differences among the preferences, with most people preferring a subjectivizer $(\mathrm{N}=50)\left[\mathrm{x}^{2}(2)=19.2, \mathrm{p}<.01\right]$. Example 7 illustrates a typical use of the subjectivizers in question: 7] 'Sizde ... hocanın numarası var mi acaba?’ = 'Do you have ... teacher's number, I
wonder?

Consultative devices (20.8\%) and hedges (15.3\%) prove prominent when we consider the fact that the rest were used only thrice at the most. Examples 8 and 9 illustrate the two, respectively: 
8] 'Buraya size bi kitap bıraksam, arkadaşım geldiğinde alsa olur mu?' = 'Is it OK/all right if I leave a book with you here and my friend gets it when she comes?'

9] '2 saniyeliğine marker alabilir miyim?' = 'Can I take (borrow) a marker for 2 seconds?'

A remarkable detail about hedges is that 13 out of the total 14 uses were combined with the strategy of 'Query Preparatory', as in 'Acaba otomasyona bakabilir miyim bi saniye?' = 'I wonder, can/may I look at the student information system for a second?'

Comparisons in this domain according to gender are provided in Table 5:

Table 5. Internal modification with lexical/phrasal devices according to gender

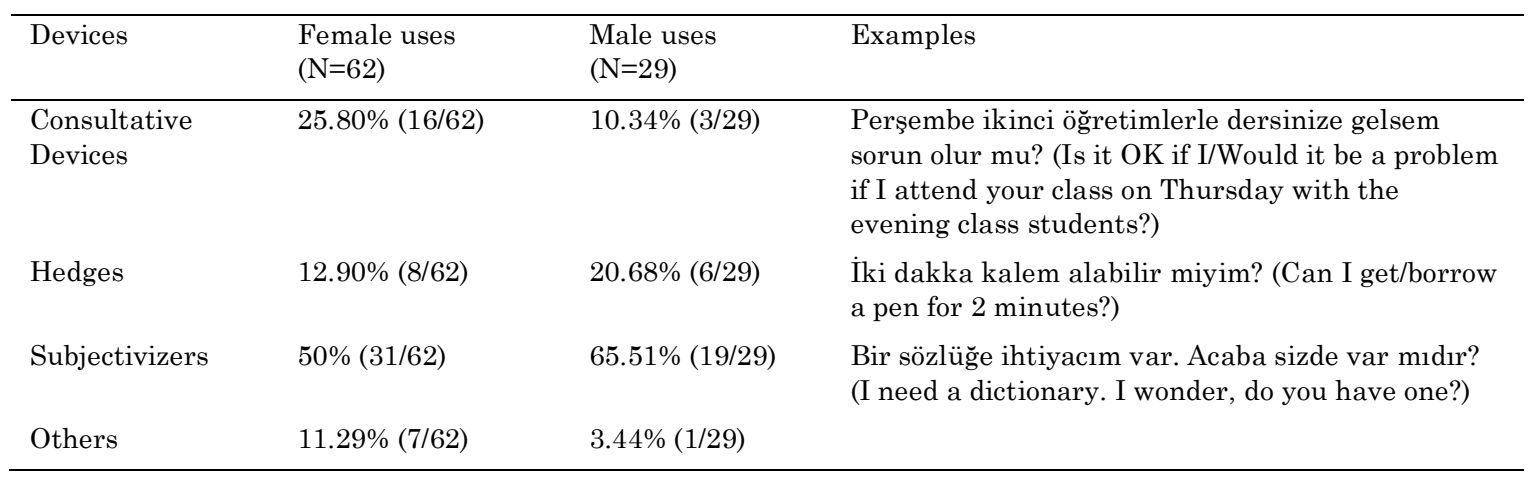

According to the chi-square test for independence implemented on the data presented in Table 5, there was no statistically significant relationship between gender and use of lexical/phrasal modification devices $\left[\mathrm{x}^{2}(3)=5.2, \mathrm{p}>.05\right]$.

The findings on the lexical/phrasal modification devices in terms of different request situations are given in Table 6:

Table 6. Internal modification with lexical/phrasal devices according to the request situations

\begin{tabular}{llllll}
\hline Device & Situations & & & \\
& $\begin{array}{l}\text { Signing } \\
(\mathrm{N}=83)\end{array}$ & $\begin{array}{l}\text { Material } \\
(\mathrm{N}=217)\end{array}$ & $\begin{array}{l}\text { PC use } \\
(\mathrm{N}=10)\end{array}$ & $\begin{array}{l}\text { Attending } \\
\text { a Different Class } \\
(\mathrm{N}=32)\end{array}$ & $\begin{array}{l}\text { Others } \\
(\mathrm{N}=53)\end{array}$ \\
\hline $\begin{array}{lllll}\text { Zero Marking } \\
\text { 'I beg you' }\end{array}$ & $89.15 \%(74)$ & $74.19 \%(161)$ & $50 \%(5)$ & $78.12 \%(25)$ & $71.69 \%(38)$ \\
Consultative & $4.81 \%(4)$ & $1.38 \%(3)$ & $10 \%(1)$ & $21.87 \%(7)$ & 0 \\
Devices & 0 & $0.46 \%(1)$ & 0 & & $7.54 \%(4)$ \\
Downtoners & 0 & 0 & 0 & 0 & $1.88 \%(1)$ \\
Hedges & $4.81 \%(4)$ & $19.81 \%(43)$ & $10 \%(1)$ & 0 & $7.54 \%(4)$ \\
Subjectivizers & $1.20 \%(1)$ & 0 & 0 & 0 & $3.77 \%(2)$ \\
Appealers & 0 & 0 & $10 \%(1)$ & 0 & $1.88 \%(1)$ \\
Time Intensifiers & 0 & 0 & $10 \%(1)$ & 0 & 0 \\
Possibility & 0 & & & & $5.66 \%(3)$ \\
Seekers & & & & 0 & \\
\hline
\end{tabular}


As Table 6 shows, in parallel with the holistic results, there was no marking in most of the requests. Nonetheless, a closer look shows some noteworthy findings: among the 56 uses in the 'requesting a material' category, subjectivizers $(\mathrm{N}=43)$ amount to $76.78 \%$, the significance of which was substantiated also by the chi-square goodness-of-fit test $\left[\mathrm{x}^{2}(2)=48.2, \mathrm{p}<.01\right]$. Besides, $100 \%$ of the modifiers employed while 'requesting to attend a different class' were consultative devices.

When we come to the domain of syntactic downgraders, we see that only four of them were used with considerable frequency. Table 7 presents the overall findings on how the requests were modified syntactically.

Table 7. Internal modification with syntactic devices (in 395 requests \& among 217 downgraders) *

\begin{tabular}{|c|c|c|c|}
\hline Downgraders & In the requests & $\begin{array}{l}\text { Among } \\
\text { themselves }\end{array}$ & Examples \\
\hline Zero Marking & $52.4 \%(207 / 395)$ & - & \\
\hline $\begin{array}{l}\text { Conditional } \\
\text { Clause }\end{array}$ & $5.56 \%(22 / 395)$ & $10.13 \%(22 / 217)$ & $\begin{array}{l}\text { Perşembe ikinci ögretimlerle dersinize girsem } \\
\text { sorun olur mu? (Is it OK if I attend your class } \\
\text { with the evening education students on } \\
\text { Thursday?) }\end{array}$ \\
\hline Tense & $5.06 \%(20 / 395)$ & $9.21 \%(20 / 217)$ & $\begin{array}{l}\text { Bi imzanızı alacaktım ama... (I was going to get } \\
\text { your signature, but...) }\end{array}$ \\
\hline Interrogative & $39.74 \%(157 / 395)$ & $\begin{array}{l}72.35 \% \\
(157 / 217)\end{array}$ & İmzalar mısınız? (Will you sign [it/this]?) \\
\hline Unfinished** & $4.55 \%(18 / 395)$ & $8.29 \%(18 / 217)$ & $\begin{array}{l}\text { Bize şöyle bir 'rod' lazım ama... (We need a rod } \\
\text { like this, but...) }\end{array}$ \\
\hline
\end{tabular}

* The number of the modifiers is not equal to that of the requests as more than one modifier was used in some cases.

** As reflective of the approach in Flöck (2016), this device was introduced for the purposes of the current study as it cannot be found in the adopted schemes (See example 12 below and Appendix C).

As seen in Table 7, more than half of the requests were not downgraded syntactically at all. Among the syntactic downgraders themselves $(\mathrm{N}=217)$, the chi-square goodnessof-fit test suggested that there were statistically significant differences in the preferences $\left[x^{2}(3)=259.6, \mathrm{p}<.01\right]$, with an overwhelming majority for 'interrogative' (72.35\%). It is worth reminding ourselves here that preparatory request strategies of the form '...-bilir misiniz? / ...-bilir miyim? = can you - could you ...? / can I-could I may $I$...?' were not treated as syntactic downgraders and therefore not included in the interrogative category, as the interrogative in such cases is unmarked (See Appendix C). In this regard, a common use of the forms covered is exemplified below:

10] 'İki dakikalık zamanınız var mı anket uygulaması için?' = 'Do you have 2 minutes' time for questionnaire completion?'

Another considerable detail is that the combination where 'Interrogative' figured most frequently was 'Hint + Subjectivizer + Interrogative ( $\mathrm{N}=34)$ ', as in 'Hocam elinizde program var mi acaba, boş sinıfların programı?' = 'Teacher, do you have the schedule, I wonder, the schedule for the unoccupied classrooms?'. In terms of frequency, conditional clause, tense and unfinished utterances follow interrogative with $10.13 \%, 9.21 \%$ and $8.29 \%$, respectively. The following exemplify these in sequence: 
11] (The student came in just before the lesson. She had agreed to get a translation assignment after that class hour): 'Hocam şimdi alsam olur mu çeviriyi?' = 'Teacher, is it OK if I get the translation now?'

12] '... Hoparlör isteyecektik biz.' = 'We were going to ask for loudspeakers.': use of past tense marker as a distancing device (Flöck, 2016, p. 107).

13] 'Hocam, şuraya imza atılması gerekiyomuş ama ...' = 'Teacher, I've heard that this part must be signed, but ...': By the way, we should note here that 7 of the 18 'Unfinished' uses were combined with hints, as in this example above.

Gender-based comparisons on syntactic modification are provided in Table 8:

Table 8. Internal modification with syntactic downgraders according to gender

\begin{tabular}{|c|c|c|c|}
\hline Downgraders & $\begin{array}{l}\text { Female } \\
\text { uses } \\
(\mathrm{N}=142)\end{array}$ & $\begin{array}{l}\text { Male } \\
\text { Uses } \\
(\mathrm{N}=75)\end{array}$ & Examples \\
\hline Interrogative & $\begin{array}{l}76.05 \% \\
(108 / 142)\end{array}$ & $\begin{array}{l}65.33 \% \\
(49 / 75)\end{array}$ & $\begin{array}{l}2 \text { dakikalık zamanınız var mı anket uygulaması için? (Have you } \\
\text { got two minutes' time for questionnaire completion?) }\end{array}$ \\
\hline Unfinished & $\begin{array}{l}5.63 \% \\
(8 / 142)\end{array}$ & $\begin{array}{l}13.33 \% \\
(10 / 75)\end{array}$ & Şöyle bir imza atabilirseniz... (If you could sign right here...) \\
\hline
\end{tabular}

According to the chi-square test for independence implemented on the data displayed in Table 8 , there was a significant relationship between gender and use of syntactic modification devices $\left[x^{2}(3)=9.3, \mathrm{p}<.05\right]$.

Finally, the results on syntactic modification in terms of different request situations are given in Table 9:

Table 9. Internal modification with syntactic devices according to request situations

\begin{tabular}{|c|c|c|c|c|c|}
\hline Device & Situations & & & & \\
\hline & $\begin{array}{l}\text { Signing } \\
(\mathrm{N}=83)\end{array}$ & $\begin{array}{l}\text { Material } \\
(\mathrm{N}=217)\end{array}$ & $\begin{array}{l}\text { PC use } \\
(\mathrm{N}=10)\end{array}$ & $\begin{array}{l}\text { Attending } \\
\text { a Different Class } \\
(\mathrm{N}=32)\end{array}$ & $\begin{array}{l}\text { Others } \\
(\mathrm{N}=53)\end{array}$ \\
\hline Zero Marking & $54.21 \%(45 / 83)$ & $33.64 \%(73 / 217)$ & $80 \%(8 / 10)$ & $56.25 \%(18 / 32)$ & $\begin{array}{l}64.15 \% \\
(34 / 53)\end{array}$ \\
\hline $\begin{array}{l}\text { Conditional } \\
\text { Clause }\end{array}$ & $8.43 \%(7 / 83)$ & $1.84 \%(4 / 217)$ & $10 \%(1 / 10)$ & $21.87 \%(7 / 32)$ & $\begin{array}{l}5.66 \% \\
(3 / 53)\end{array}$ \\
\hline Tense & $6.02 \%(5 / 83)$ & $6.91 \%(15 / 217)$ & 0 & 0 & 0 \\
\hline Interrogative & $22.89 \%(19 / 83)$ & $52.99 \%(115 / 217)$ & $10 \%(1 / 10)$ & $21.87 \%(7 / 32)$ & $\begin{array}{l}28.30 \% \\
(15 / 53)\end{array}$ \\
\hline Unfinished & $8.43 \%(7 / 83)$ & $4.60 \%(10 / 217)$ & 0 & 0 & $\begin{array}{l}1.88 \% \\
(1 / 53)\end{array}$ \\
\hline
\end{tabular}


As Table 9 shows, there was no marking in more than half of the requests except for the 'requesting a material' situation, where the frequency of 'Interrogative' is greater than even zero marking and the chi-square goodness-of-fit test suggested that there were statistically significant differences in the preferences $\left[x^{2}(4)=218.3, p<.01\right]$. Another noteworthy result is that, in the 'signing a document' situation, the preferences for 'Interrogative' $(\mathrm{N}=19)$ among the 38 uses amount to $50 \%$.

Apart from all these, a qualitative look at the data reveals some additional findings worth mentioning. In 333 of the 395 requests, the attention-getter 'hocam' = 'my teacher' was used as an all-purpose device in all the request situations by the members of all the request types. Another considerable detail concerns the combination of the head act strategies with downgraders. When the subjects used the direct strategies of 'want' and 'need' statements, they softened most of them with downgraders. Out of the 10 need statements, one was combined with the syntactic downgrader 'Tense' and 6 were with 'Unfinished', as in 'Çeviri sınavı için bir sözlüğe ihtiyacımız var ama...' = 'We need a dictionary for the Translation exam, but...'. In 5 of the 7 want statements, they did it with 'Tense', as in 'Makas isteyecektim ben.' = 'I was going to ask for scissors.'

\section{Discussion}

This study aimed to document how undergraduate native speakers (NS) of Turkish formulate their naturally occurring requests in a specific context, where they asked an academic in his office to do something for them. Accordingly, the requesting preferences with their degree of directness and internal modification devices were investigated in relation to gender and different request situations.

Firstly, an overview of the results shows that the strongest tendency was towards conventionally indirect strategies (at a rate of $52.4 \%$ ). Non-conventional indirectness was also preferred to a considerable extent (40\%) while the direct strategies emerged with significantly lower frequencies (7.6\%). These all agree with the findings in Economidou-Kogetsidis' (2013) natural data and with the postulation that people feel the pressing need in real encounters to be more polite and thus less direct, with the underlying motivation for engaging in face-work (Rintell \& Mitchell, 1989). What is more, the hearer of the requests in this study had a relatively higher status as the current or prospective teacher of the requesters and, as the related literature puts it, less direct strategies would be used more in low-high request situations (Blum-Kulka et al., 1989; Brown \& Levinson, 1987), where people tend to deem conventional indirectness 'least impolite' (Culpeper, 2011; Vergis \& Terkourafi, 2015).

The gender-related findings display the even clearer female tendency towards conventional indirectness (at a rate of 57.8\%). In light of the fact that conventionally indirect strategies have been labelled the most polite in different languages (BlumKulka, 1987), one can argue that this finding from the area of Turkish pragmatics would confirm the classical theory suggesting that females often prove more polite in language use (Aitchison, 1992; Güney, 2015; Holmes, 1995; Lakoff, 1975; Shams \& Afghari, 2011). This tendency for women to speak closer to the prestige standard was 
explained with the proposition that they speak nicely as the main child-rearers to help their children progress socially, or that they tend to have jobs that rely on communication rather than strength (Aitchison, 1992). Karagöz and İşisağ's recent study (2019) with participants remarkably similar to those in this one reports that the females acted more politely when performing their requests. This is attributed to the abovementioned theory and a notion that had already been corroborated as specific also to Turkish culture, where women's language shows distance from power until they can earn a living (Zeyrek, 2001), while male speech indicates self-assertion (Hayasi, 1998), and keeping conversational distance with men is a female sensitivity (Bayyurt \& Bayraktaroğlu, 2001). Nonetheless, the annotation should be here that the notion of women to necessarily act more decorously is challenged by the trends in sociolinguistics and discursive pragmatics, for such a presupposition might amount to stereotyping (Coates, 2015) and considering gender a monolithic concept (Spitz, 2005), while women's talk in interaction needs a context-specific approach drawing on the notion of 'communities of practice' (Eckert \& McConnell-Ginet, 1995; Mills, 2003). In this regard, the researcher's style of speech with students of different genders might have been accommodated by the participants, where gender (like other social variables) would be viewed not as static, but as co-constructed in the interpersonal relationship aspects of that specific interactional context.

As for the findings on the strategies in different request situations, we see that conventional indirectness was overwhelmingly dominant when the degree of imposition was higher, such as when the subjects employed it at a $100 \%$ rate to ask to use the researcher's computer. High imposition that called for conventionally indirect strategies could take on a meaning if we revisit the fact that people tend to consider them the politest means of requesting in different languages (Blum-Kulka, 1987; Jalilifar, 2009). Specifically regarding Turkish, while Aslan (2005) underscored the face-saving function of hinted requests, Martı (2006) reported the perceived politeness attached to conventional indirectness in a situation-specific manner, expressing also the reservation that conventionally indirect forms might not be the only (or most) polite strategy. This line of argument can be supported with some other findings of the current study, i.e. that the strategies did vary, and that non-conventionally indirect and even the most direct forms came into play when the subjects asked the researcher to sign a document or to provide a material or a small item of stationery, where the imposition was lower. Signing those documents was a responsibility for the researcher, and those materials must have been thought to be within his arm's reach. The reason why the students abundantly produced non-conventionality (at a $55.8 \%$ rate) while requesting such materials and gadgets may be that they tended to do it mostly by questioning the feasibility of the requested act, i.e. by asking whether or not the requested thing existed in the researcher's office, which is a substrategy of non-conventional indirectness (Weizman, 1989). They employed it in 112 of the 121 hinted requests, even though they were almost entirely sure that things like a board marker would be found in the office of active teachers. 
The findings on non-conventionality are especially important in terms of what naturalistic data-based studies can offer. We see that pragmatic analysis with corpora, an alternative design deemed not to suffer from lack of authenticity, and therefore viable (Leech, 2011), might turn out to be inadequate in that respect, as nonconventionally indirect strategies may not even be included. Aksan and Mersinli's (2015) corpus-based study on Turkish requestives is an illustrative example, where the researchers had to confine their analyses only to some predetermined formal representations of 'direct and conventionally indirect strategies', since 'nonconventionally indirect ones' had proved incalculable, which makes the study a decontextualized one that reports the naturalness restrictedly. In this regard, findings from studies using natural data can help corpus-based designs by adding to their repertoire of linguistic tokens of non-conventionality to be sought and extracted from corpora.

An overview of the internal modification findings suggests that 'zero marking' characterized the majority of the data (at a rate of $78.7 \%$ ). This is congruent with Economidou- Kogetsidis' (2013) data for natural requests, where zero marking was more frequent than the total of all the other lexical/phrasal modification devices. Aksan and Mersinli's (2015) corpus-based study on requestives in Turkish yielded a very similar result, while it had previously been argued that Turkish speakers rely heavily on such modifiers. The absence of 'please' is another notable result when we consider the postulations that adding 'please' will affect levels of politeness in all languages (Blum-Kulka, 1987), and that it is the most salient of the commonest politeness strategies to show respect to the interlocutor and politely ask for his/her cooperation (Alemi \& Razzaghi, 2013). In this regard, the case in the present study could be language- and/or context-specific, which requires complementary qualitative research into the underlying motives. Moreover, we see that the subjectivizer 'acaba' = 'I wonder' played the role defined for 'please'. It was used more frequently than the total of all the other devices. Its dominance was maintained also in the findings from the specific perspectives of gender. The male subjects showed an even clearer tendency towards it. Considering the fact that 'acaba' in Turkish can accompany questions where the speaker wishes to express deference to the addressee (Göksel \& Kerslake, 2005) and that it can come into play in situations where the social distance between the interlocutors is great (Martı, 2006), we can hypothesize that the male subjects tended to use it to compensate for their lower levels of politeness in the head act strategies. As for the findings on different request situations; what prevails is the fact that 'getting an official document signed' was the one with the lowest proportion of device uses (with a zero marking rate of $89.1 \%$ ), which could mean that the subjects did not feel the need for extra politeness there. Signing such documents was a statutory responsibility for the researcher, so this finding is in harmony with Ervin-Tripp's (1996) finding that a major determinant of request mitigation is asking for something outside of role. This seems to be confirmed by the finding that the situation with the highest proportion of device uses (at a 50\% rate) was when the subjects asked to use the researcher's PC, which would normally be considered beyond the call of duty. Another result of note is 
that $100 \%$ of the modifiers employed for 'requesting the right to attend a lesson in a different class from the regular one' were consultative devices, which suggests that they could be the norm in such requests.

The findings on syntactic modification firstly suggest that 'conditional structure', 'aspect' and 'negation', which are all conceptualized in the request modification schemes utilized in the related literature, appear not to exist as viable downgraders in Turkish in the context of this study. None was preferred on any of the 217 occasions when syntactic downgraders were used. There was a similar finding about 'cajolers' in terms of the lexical/phrasal modifiers (See Appendices B and C). Besides these, we see that 'zero marking' constituted a significant majority (at a $52.4 \%$ rate), which conforms to the findings of this study on lexical/phrasal modification and Economidou-Kogetsidis' (2013) data for natural requests. When the subjects chose to modify their utterances syntactically, they did it mostly with interrogative utterances (at a rate of $72.3 \%$ among all the device uses). An interesting result is that 'unfinished sentences' formed another considerable part (at an $8.2 \%$ rate). They were left unfinished mostly with 'ama' = 'but' or 'de/da', i.e. suffixes that can be used as a conjunction with the function of 'so' as a link between a cause clause and an effect clause. Similar to what is stated in Norrick (2009), none of them is final; instead, they are followed by a pause that a second speaker could fill with a new turn. They are meant to function as an 'unstated upshot' (Raymond, 2004) enabling the speaker to anticipate some kind of response (Beck, 2015). Not found in the adopted classification schemes, they asserted themselves as an additional category in the analyses for the purposes of the current study in the way Flöck (2016) did. This is another finding that could be considered language- or contextspecific. The gender-related perspective showed that using the downgrader 'Tense', as in 'Makas isteyecektim ben' = 'I was going to ask for scissors', seems more like a masculine tendency as their second-best preference. The fact that 'tense' as a modifier was employed considerably by the NS subjects of the study complies with the reports that language learners would be expected to use it in light of the NS performances taken as base-line cultural data (Bella, 2012), but they fail in the sense that such structures take time to be acquired (Ko, Eslami, \& Burlbaw, 2015). The reasons why it was used more frequently by the male subjects of this study, however, need additional qualitative investigation in order to be understood. As some interactional particles exist in Japanese (Masuda, 2011), there could be forms and devices in Turkish that sound more masculine or feminine.

As for the findings on syntactic modification with respect to different request situations, 'requesting a material' is the only situation where 'Interrogative' dominated in comparison to all the other preferences (at a $52.9 \%$ rate). As previously mentioned, the subjects requested such materials, items and gadgets mostly by investigating the feasibility of the requested act, i.e. by just asking whether the requested thing existed in the setting. It is interesting that they did not prefer to do it more with 'an ability question + feasibility investigation in a conditional clause', such as '...Bi tahta kaleminiz varsa alabilir miyim?' = '.. Can/May I get/borrow a board marker if you have one?', which would have generated more politeness while still investigating the feasibility of 
the requested act. Findings like this may open the door to qualitative studies on discovering the motives behind the request preferences.

In addition to all these, despite not being in the direct scope of the study, we must remind ourselves that 'hocam' = 'my teacher' was found to provide a safety zone as an attention-getter to accompany any kind of actual request in a context like that of the current study. This has its echo in Doğançay-Aktuna and Kamışlı's (2001) study, which reports that Turkish students use 'hocam' as a respectfully polite attention-getter in almost all instances of address from students to the teacher. Apart from that, the fact that most of the 'want' and 'need' statements were softened with downgrader combinations should be attributed to their potential risk of impoliteness due to being among the most direct head act strategies.

\section{Conclusions}

Although there is a large amount of research on requests (Gagne, 2018) as intrinsically face-threatening acts (Márquez Reiter, Ganchenko, \& Charalambidou, 2016), there has been little natural data-based investigation into the interactions where speakers select one request form rather than another (Curl \& Drew, 2008). Within this framework, the current study illuminates the naturally occurring pragmatics of a context where undergraduates spontaneously request an academic to do something for them while s/he is in her/his office, and to the best of the researcher's knowledge, no study based on natural data has been published with such a focus.

The results on the main strategies reveal that the strongest tendency is towards conventionally indirect strategies. As was the case when it prevailed as the favorite strategy to make a request from the higher-status researcher, and when the females, as reportedly more polite speakers, preferred it more clearly, 'conventional indirectness' was dominant also in the situations where the imposition was higher.

'No marking with lexical/phrasal devices' characterized the majority of the findings. The specific subjectivizer 'acaba' = 'I wonder', however, was found to assume the universal role credited to the marker 'please'. Besides, mitigation with such devices for more politeness became more frequent as the imposition became higher.

The findings about syntactic modification show parallelism with those on lexical/phrasal downgraders in terms of the majority of 'zero marking'. A particularly interesting result is that 'unfinished utterances' asserted itself as an additional analytic category. In addition, the findings such as the clear male tendency towards the downgrader 'Tense' raised the question of whether there could be some forms in Turkish that sound more masculine or feminine. Finally, it was revealed that the downgrader 'interrogative' seemed to be the norm when requesting a material, tool or gadget, for the requesters mostly did this by just asking whether the requested thing existed in the setting.

With its descriptive findings based on longitudinal spontaneous data, this study sheds light on Turkish pragmatics in a relatively everyday context. This could help it 
serve both teachers and learners of Turkish when we consider the facts that while the number of international students at Turkish universities was around 55,000 in 2014, it was announced as 102,843 in 2018, and that teaching Turkish to speakers of other languages has been featuring prominently as a specialist field (Erişti, Polat, \& Erdem, 2018 ) in parallel with the practice of teaching it as a heritage or community language (Otcu-Grillman, 2016). The study could prove useful for Turkish learners of EFL or any other language as well. If we compare its findings with elicited and/or natural data on how learners make requests in the target language in similar contexts, we could reveal the transfer effects from Turkish as their L1. In addition, if we produce DCT situations based on the ones that emerged in this study, it could contribute in the realm of Turkish pragmatics to the efforts for handling the validity concerns about DCTs, related to the extent to which elicited data can represent what people say in natural conversation.

A limitation of this study is that it addressed one specific situation. Besides, the data, which relied on the researcher's memory, did not enable analytic attention to be directed to the sequential and temporal organization of interaction so that the requests could be studied as situated and coordinated actions-in-interaction, the significance of which has been documented by the discursive turn in pragmatics. In this regard, natural data from a case like the one in this study could be gathered and examined by researchers in any language with better control of the situational operants by using a more sophisticated system of recording, which can pave the way for similar studies by even including variables such as external moves and other vocal and non-vocal linguistic and non-linguistic aspects of interactional conduct not amenable to ethnographic field notes (Kasper, 2006).

\section{Acknowledgements}

An earlier version of this paper was presented at the V. Uluslararası Multidisipliner Çalışmaları Sempozyumu (ISMS) 2018 in Ankara.

\section{The Conflict of Interest Statement}

In line with the statement of Committee on Publication Ethics (COPE), I hereby declare that we had no conflicting interests regarding any parties of this study.

\section{References}

Aitchison, J. (1992). Linguistics. London: Hodder \& Stoughton.

Aksan, M., \& Mersinli, Ü. (2015). Retrieving and analyzing requestive forms: Evidence from the Turkish National Corpus. In S. Ruhi \& Y. Aksan (Eds.), Exploring (im)politeness in specialized and general corpora: converging methodologies and analytic procedures (pp. 169215). Newcastle upon Tyne: Cambridge Scholars Publishing.

Alemi, M., \& Razzaghi, S. (2013). Politeness markers in English for business purposes textbook. International Journal of Research Studies in Language Learning, 2(4), 109-123. https://doi.org/10.5861/ijrsll.2012.191

Aslan, S. (2005). Türkiye Türkçesinde sezdirmeye dayalı rica stratejileri. Modern Türklük Araştırmaları Dergisi, 1, 114-126. 
Bayyurt, Y., \& Bayraktaroğlu, A. (2001). The use of pronouns and terms of address in Turkish service encounters. In A. Bayraktaroğlu \& M. Sifianou (Eds.), Linguistic politeness across boundaries. The case of Greek and Turkish (pp. 209-240). Amsterdam: John Benjamins. https://doi.org/10.1075/pbns.88.09bay

Beck, J. (2015). So What? What it means when people leave the word "so" dangling at the end of a sentence. Retrieved from https://www.theatlantic.com/technology/archive/20 15.

Beebe, L., \& Cumming, M. C. (1996). Natural speech act data versus written questionnaire data: How data collection method affects speech act performance. In S. Gass \& J. Neu (Eds.), Speech acts across cultures: Challenges to communication in a second language (pp.65-86). New York: Mouton de Gruyter.

Bella, S. (2012). Pragmatic development in a foreign language: A study of Greek FL requests. Journal of Pragmatics, 44(13), 1917-1947. https://doi.org/10.1016/j.pragma.2012.08.014

Billmyer, K., \& Varghese, M. (2000). Investigating instrument-based pragmatic variability: Effects of enhancing discourse completion tests. Applied Linguistics, 21(4), 517-552. https://doi.org/10.1093/applin/21.4.517

Boyac1, A. (2011). Erasmus exchange students' comparative views on classroom management in Turkey and in their country (Anadolu University case). Education and Science, 36(159), 270282.

Blum-Kulka, S. (1987). Indirectness and politeness in requests: Same or different? Journal of Pragmatics, 11(2), 131-146. https://doi.org/10.1016/0378-2166(87)90192-5

Blum-Kulka, S. (1989). Playing it safe: The role of conventionality and indirectness. In S. BlumKulka, J. House \& G. Kasper (Eds.), Cross-cultural pragmatics. Requests and apologies (pp. 37-70). Norwood, NJ: Ablex.

Blum-Kulka, S., \& Olshtain, E. (1984). Requests and apologies: A cross-cultural study of speech act realization patterns (CCSARP). Applied Linguistics, 5(3), 196-213. https://doi.org/10.1093/applin/5.3.196

Blum-Kulka, S., House, J., \& Kasper, G. (1989). Cross-cultural pragmatics: Requests and apologies. Norwood, NJ: Ablex Publishing.

Brown, P., \& Levinson, S. C. (1987). Politeness: Some universals in language use. Cambridge: Cambridge University Press. https://doi.org/10.1017/CBO9780511813085

Coates, J. (2015). Women, men and language: A sociolinguistic account of gender differences in language. London: Routledge. https://doi.org/10.4324/9781315645612

Culpeper, J. (2011). Impoliteness. Using language to cause offence. Cambridge, England: Cambridge University Press.

Curl, T. S., \& Drew, P. (2008). Contingency and action: A comparison of two forms of requesting. Research on Language and Social Interaction, 41(2), 129-153. https://doi.org/10.1080/08351810802028613

Doğançay-Aktuna, S., \& Kamışll, S. (2001). Linguistics of power and politeness in Turkish: Revelations from speech acts. In A. Bayraktaroğlu \& M. Sifianou (Eds.), Linguistic politeness across boundaries: The case of Greek and Turkish. (pp. 75-104). Amsterdam: John Benjamins. https://doi.org/10.1075/pbns.88.05dog

Economidou-Kogetsidis, M. (2013). Strategies, modification and perspective in native speakers' requests: A comparison of WDCT and naturally occurring requests. Journal of Pragmatics, 53, 21-38. https://doi.org/10.1016/j.pragma.2013.03.014

Eckert, P., \& McConnell-Ginet, S. (1995). Constructing meaning, constructing selves: Snapshots of language, gender and class from Belten High. In M. Bucholtz \& K. Hall (Eds.), Gender articulated: Language and the culturally constructed self (pp. 469-507). London: Routledge. 
Eriş̧i, B., Polat, M., \& Erdem, C. (2018). Yükseköğretimde uluslararasılaşma: Uluslararası öğrencilerin bulunduğu sinıflarda ders veren öğretim elemanlarının öğretim sürecinde yaşadıkları sorunlar ve çözüm önerileri. Journal of History Culture and Art Research, 7(2), 352-375. http://dx.doi.org/10.7596/taksad.v7i2.1539

Ervin-Tripp, S. M. (1996). Context in language. In D. I. Slobin, J. Gerhardt, A. Kyratzis, \& J. Guo (Eds.), Social interactions, social context, and language (pp. 21-38). Hillsdale, NJ: Lawrence Erlbaum.

Faerch, C., \& Kasper, G. (1989). Internal and external modification in interlanguage request realization. In S. Blum-Kulka, J. House \& G. Kasper (Eds.), Cross-cultural pragmatics: Requests and apologies (pp. 221-247). Norwood, NJ: Ablex.

Félix-Brasdefer, J. C. (2010). Data collection methods in speech act performance: DCTs, role plays, and verbal reports. In A. Martínez-Flor \& E. Usó-Juan (Eds.), Speech act performance: Theoretical, empirical, and methodological issues (pp. 41-56). Amsterdam: John Benjamins. https://doi.org/10.1075/1llt.26.03fel

Flöck, I. (2016). Requests in American and British English: A contrastive multi-method analysis. Amsterdam: John Benjamins. https://doi.org/10.1075/pbns.265

Gagne, C. (2018). Indirectness and entitlement in product requests in British service encounters. Journal of Pragmatics, 133, 1-14. doi.org/10.1016/j.pragma.2018.05.015

Golato, A. (2005). Compliments and compliment responses: Grammatical structure and sequential organization. Amsterdam and Philadelphia, PA: John Benjamins. https://doi.org/10.1075/sidag.15

González-Cruz, M. I. (2014). Request patterns by EFL Canarian Spanish students: Contrasting data by languages and research methods. Intercultural Pragmatics, 11(4), 547- 573. https://doi:10.1515/ip-2014-0024

Göksel, A., \& Kerslake, C. (2005). Turkish: An essential grammar. London: Routledge.

Güney, S. (2015). Sosyal psikoloji. Ankara: Nobel Akademik Yayıncılık.

Hayasi, T. (1998). Gender differences in modern Turkish discourse. International Journal of the Sociology of Language, 129(1), 117-126. https://doi.org/10.1515/ijsl.1998.129.117

Hinkel, E. (1997). Appropriateness of advice: DCT and multiple-choice data. Applied Linguistics, 18(1), 1-26. https://doi.org/10.1093/applin/18.1.1

Holmes, J. (1995). Women, men and politeness. London: Longman.

Huddleston, R., \& Pullum, G. K. (2002). The Cambridge grammar of English language. Cambridge: Cambridge University Press.

Huls, E. (1988). Politeness phenomena in the directives used by Turkish migrant families in the Netherlands. In S. Koç (Ed.), Studies in Turkish linguistics (pp. 1-25). Ankara: Middle East Technical University Press.

Jalilifar, A. (2009). Request strategies: Cross-sectional study of Iranian EFL learners and Australian native speakers. English Language Teaching, 2(1), 46-61. https://doi:10.5539/elt.v2n1p46

Karagöz, T., \& İşisağ, K. U. (2019). An Investigation into the request realization patterns of Turkish ELT students. Novitas-ROYAL (Research on Youth and Language), 13(1), 84-102.

Kasper, G. (1992). Pragmatic transfer. Second Language Research, 8(3), 203-231. https://doi.org/10.1177/026765839200800303

Kasper, G., \& Rose, K. R. (2002). Pragmatic development in a second language. Oxford: Blackwell.

Kasper, G. (2006). Speech acts in interaction: Towards discursive pragmatics. In K. BardoviHarlig, C. Félix-Brasdefer, \& A. Omar (Eds.), Pragmatics and language learning, Vol. 11 (pp. 281-314). Honolulu: University of Hawai'i, National Foreign Language Resource Center. 
Ko, S., Eslami, Z. R., \& Burlbaw, L. M. (2015). Investigating non-native English-speaking graduate students' pragmatic development in requestive emails. International Journal of Society, Culture \& Language, 3(1), 1-15.

Lakoff, R. (1975). Language and woman's place. New York: Harper and Row.

Leech, G. (2011). Principles and applications of corpus linguistics. In V. Viana, S. Zyngier \& G. Barnbrook (Eds.), Perspectives on corpus linguistics (pp. 155-170). Amsterdam/Philadelphia: John Benjamins.

Leech, G.N., \& Thomas, J. (1990). Language, meaning and context: Pragmatics. In N.E. Collinge (Ed.), Encyclopedia of language (pp. 173-206). London: Routledge.

Márquez Reiter, R., Ganchenko, K., \& Charalambidou, A. (2016). Requests and counters in Russian traffic police officer-citizen encounters. Pragmatics and Society, 7(4), 512-539. https://doi.org/10.1075/ps.7.4.01mar

Martı, L. (2006). Indirectness and politeness in Turkish-German bilingual and Turkish monolingual requests. Journal of Pragmatics, 38(11), 1836-1869. https://doi.org/10.1016/j.pragma.2005.05.009

Masuda, K. (2011). Acquiring interactional competence in a study abroad context: Japanese language learners' use of the interactional particle ne. The Modern Language Journal, 95(4), 519-540. https://doi.org/10.1111/j.1540-4781.2011.01256.x

Mills, S. (2003). Gender and politeness. Cambridge: Cambridge University Press.

Norrick, N. R. (2009). Conjunctions in final position in everyday talk. In B. Fraser \& K. Turner (Eds.), Language in life, and a life in language: Jacob Mey - a festschrift (pp. 319-328). Bingley: Emerald. https://doi: 10.1163/9789004253209_041

Otcu-Grillman, B. (2016). "Speak Turkish!" or not? Language choices, identities and relationship building within New York's Turkish community. International Journal of the Sociology of Language, 237, 161-181. https://doi:10.1515/ijsl-2015-0040

Raymond, G. (2004). Prompting action: The stand-alone" so" in ordinary conversation. Research on Language and Social Interaction, 37(2), 185-218. https://doi.org/10.1207/s15327973rlsi3702_4

Ren, W. (2019). Pragmatic development of Chinese during study abroad: A cross-sectional study of learner requests. Journal of Pragmatics, 146, 137-149. https://doi.org/10.1016/j.pragma.2019.01.017

Rintell, E., \& Mitchell, C. (1989). Studying request and apologies: An inquiry into method. In S. Blum-Kulka, J. House \& G. Kasper (Eds.), Cross cultural pragmatics: Requests and apologies (pp. 248-272). Norwood, NJ: Ablex.

Schauer, G. (2009). Interlanguage pragmatic development: The study abroad context. London: Continuum.

Shams, R., \& Afghari, A. (2011). Effects of culture and gender in comprehension of speech acts of indirect requests. English Language Teaching, 4(4), 279-287. http://dx.doi.org/10.5539/elt.v4n4p279

Sifianou, M. (1992). Politeness phenomena in England and Greece: A cross-cultural perspective. Oxford, UK: Clarendon Press.

Spitz, A. (2005). Power plays: The representation of mother-daughter disputes in contemporary plays by women. A study in discourse analysis. (Unpublished Doctoral Dissertation). Universität des Saarlandes, Saarbrücken.

Taguchi, N. (2018). Description and explanation of pragmatic development: Quantitative, $\begin{array}{llll}\text { qualitative, and mixed methods research. System, } & \text { 23-32. }\end{array}$ https://doi.org/10.1016/j.system.2018.03.010 
Vergis, N., \& Terkourafi, M. (2015). The role of the speaker's emotional state in im/politeness assessments. Journal of Language and Social Psychology, 34(3), 316-342. https://doi.org/10.1177/0261927X14556817

Weizman, E. (1989). Requestive hints. In S. Blum-Kulka, J. House \& G. Kasper (Eds.), Crosscultural pragmatics: Requests and apologies (pp. 71-95). Norwood, NJ: Ablex.

Will. (n.d.) In Cambridge dictionary. Retrieved April 15, 2020 from https://dictionary.cambridg e.org/grammar/british-grammar/modals-and- modality/will

Yuan, Y. (2001). An inquiry into empirical pragmatics data-gathering methods: Written DCTs, oral DCTs, field notes, and natural conversations. Journal of Pragmatics, 33(2), 271-292. https://doi.org/10.1016/S0378-2166(00)00031-X

Zeyrek, D. (2001). Politeness in Turkish and its linguistic manifestations. In A. Bayraktaroğlu \& M. Sifianou (Eds.), Linguistic politeness across boundaries. The case of Greek and Turkish (pp. 43-73). Amsterdam: John Benjamins. https://doi.org/10.1075/pbns.88.04zey

\section{Appendix A. Degree of requestive directness - coding categories}

\begin{tabular}{|c|c|c|}
\hline Level of Directness & Request strategies & Examples \\
\hline \multirow[t]{5}{*}{ Most direct } & Imperative & $\begin{array}{l}\text { İmzalayın lütfen. (Sign } \\
\text { please.) }\end{array}$ \\
\hline & Ellipsis & Kalem? (A pen?) \\
\hline & Performative & $\begin{array}{l}\text { Bunu imzalatmaya } \\
\text { geldim. (I have come to } \\
\text { get this signed.) }\end{array}$ \\
\hline & Want statements & $\begin{array}{l}\text { Hoparlör isteyecektik. } \\
\text { (We were going to ask } \\
\text { for loudspeakers.) }\end{array}$ \\
\hline & Need statements & $\begin{array}{l}\text { Brown'un kitabı lazım } \\
\text { bana. (I need Brown's } \\
\text { book.) }\end{array}$ \\
\hline \multirow[t]{2}{*}{$\begin{array}{l}\text { Conventionally } \\
\text { indirect }\end{array}$} & Suggestory formulae & $\begin{array}{l}\text { Siz imzalasaniz? (What if } \\
\text { you sign [it]?) }\end{array}$ \\
\hline & $\begin{array}{l}\text { Query preparatory } \\
\text { (ability, willingness, } \\
\text { permission) }\end{array}$ & $\begin{array}{l}\text { Soruları yazıp size versek } \\
\text { cevaplar mısınız? (Would } \\
\text { you answer the questions } \\
\text { if we wrote [them] down } \\
\text { and gave [them] to you?) }\end{array}$ \\
\hline \multirow{2}{*}{$\begin{array}{l}\text { Non-conventionally } \\
\text { Indirect }\end{array}$} & Hints & Ben şimdi konuştum ... \\
\hline & & $\begin{array}{l}\text { hocayla da, yoldaymış. } \\
\text { Bunu (dosyayı) buraya } \\
\text { birakmamı söyledi. } \\
\text { (I have just talked to } \\
\text {... teacher, she is on the } \\
\text { road. She has told me to } \\
\text { leave this [the file] here.) }\end{array}$ \\
\hline
\end{tabular}


Appendix B. Internal modification: the classification scheme lexical/phrasal downgraders

\begin{tabular}{|c|c|}
\hline Downgraders & Devices \\
\hline Marker 'nolur' & Nolur! (I beg you!) \\
\hline \multirow[t]{2}{*}{ Consultative Devices a } & Hocam otomasyondan kontenjanlara bi \\
\hline & $\begin{array}{l}\text { baksak olur mu? (Teacher is it OK if / would } \\
\text { it be OK if / is it all right if we have a look at } \\
\text { the quotas via the automation system?) [During } \\
\text { the course enrolment period, this student asked the } \\
\text { researcher as the academic advisor to allow him to } \\
\text { look at the free course quotas via the Student } \\
\text { Affairs Information System on the office PC, for the } \\
\text { Internet connection on his mobile phone had } \\
\text { proved too slow.] }\end{array}$ \\
\hline Downtoners ${ }^{b}$ & $\begin{array}{l}\text { Müsaadenizle ben } 18.45 \text { gibi çlkabilir } \\
\text { miyim? (Can I leave at about } 18.45 \text { with your } \\
\text { permission?) }\end{array}$ \\
\hline Hedges $^{c}$ & $\begin{array}{l}2 \text { saniyeliğine marker alabilir miyim? } \\
\text { (Can I take/borrow a marker for two seconds?) }\end{array}$ \\
\hline Subjectivizers ${ }^{\mathrm{d}}$ & $\begin{array}{l}\text { Daksiliniz var mı acaba? (Do you have } \\
\text { correction fluid I wonder?) }\end{array}$ \\
\hline Appealers ${ }^{\mathrm{e}}$ & $\begin{array}{l}\text { Derse misafir kabul ediyorsunuz di mi? } \\
\text { (You accept guests into your classroom, } \\
\text { right/don't you?) }\end{array}$ \\
\hline Time Intensifiers ${ }^{f}$ & $\begin{array}{l}\text { Hemen bi şeye bakabilir miyim } \\
\text { otomasyonda? (Can I look right away at } \\
\text { something on the information system?) }\end{array}$ \\
\hline \multirow[t]{4}{*}{ Possibility Seekers ${ }^{g}$} & Cevap anahtarına bakma \\
\hline & şansımız var mi? (Do we / Would \\
\hline & we have the chance to see the answer \\
\hline & key?) \\
\hline \multirow[t]{3}{*}{ Cajolers ${ }^{\mathrm{h}}$} & Biliyorsunuz (ki) ... / \\
\hline & Görüyorsunuz (ki) ... (You know \\
\hline & (that) ... / You see (that) ...) \\
\hline
\end{tabular}

a 'Expressions by means of which the speaker seeks to involve the hearer directly bidding for cooperation' (Blum-Kulka et al.,1989, p. 283).

b 'Elements by means of which the speaker modulates the impact his/her utterance is likely to have on the hearer, achieving the modulation via devices signaling the possibility of non-compliance' (Blum-Kulka and Olshtain, 1984, p. 204). 
c 'Adverbial modifiers by means of which the speaker underrepresents the state of affairs denoted in the proposition' (Blum-Kulka et al., 1989a, p. 283).

$d$ 'Elements in which the speaker explicitly expresses his or her subjective opinion visà-vis the state of affairs referred to in the proposition, thus lowering the assertive force of the request' (Blum-Kulka et al.,1989, p. 284).

e 'Addressee-oriented elements occurring in a syntactically final position. They may signal turn-availability and are used by the speaker whenever he or she wishes to appeal to his or her hearer's benevolent understanding' (Blum-Kulka et al., 1989, p. 285).

f 'Elements employed to emphasize the temporal aspect of the speaker's request' (Schauer, 2009, p. 91). In a similar way to the approach in Flöck (2016), this kind of device was added from Schauer (2009) for the purposes of the present study, as it cannot be found in the adopted coding schemes.

g As done by Flöck (2016), specifically about the mitigating modification that can be called 'Questioning possibility', the need was felt to introduce this kind of device for the purposes of the current study as it cannot be found in the adopted coding schemes. ('... şansım(1z) var mı?' = 'Do/Would I/we have the chance to ...?), which is a relatively frequent chunk in Turkish, could be a representative example of this category.

$\mathrm{h}$ 'Conventionalized, addressee-oriented modifiers whose function is to make things clearer for the addressee and invite him/her to metaphorically participate in the speech act' (Sifianou, 1992, p. 180). None of the participants used these in this study.

Appendix C. Internal modification: the classification scheme
-- lexical/phrasal downgraders

\begin{tabular}{ll}
\hline Downgraders & Examples \\
\hline Conditional & $\begin{array}{l}\text { Perşembe ikinci öğretimlerle dersinize girsem sorun } \\
\text { olur mu? (Is it OK if I attend your class with the evening } \\
\text { education students on Thursday?) }\end{array}$ \\
\hline Tense & $\begin{array}{l}\text { Bi imzanızı alacaktım ama... (I was going to get your } \\
\text { signature, but... a) }\end{array}$ \\
\hline Interrogative & Imzalar mısınız? (Will you sign [it/this]? b) \\
\hline Unfinished & $\begin{array}{l}\text { Bize şöyle bir 'rod' lazım(dı) ama / da ... (We need[ed] a } \\
\text { rod like this, but... c) }\end{array}$ \\
\hline $\begin{array}{l}\text { Conditional } \\
\text { Structure }\end{array}$ & $\begin{array}{l}\text { Bu haftalık başka bir sinıfınızla derse girmek } \\
\text { for this week.) [This is a hypothetical example, as none of the } \\
\text { participants used this downgrader in the present study.] }\end{array}$ \\
\hline Aspect & $\begin{array}{l}\text { Bu haftalık başka bir sinıfinızla derse girip } \\
\text { giremeyeceğimi merak ediyordum. } \\
\text { (I was wondering if I could attend a different class of yours } \\
\text { for this week.) [This is a hypothetical example, as none of the }\end{array}$ \\
\hline
\end{tabular}




\begin{tabular}{ll}
\hline & participants used this downgrader in the present study.] \\
\hline Negation of & Bu haftalık başka bir sinufinızla derse giremem \\
preparatory & herhalde / girebileceğimi zannetmiyorum. \\
condition & (I could probably not attend / I don't suppose I can \\
& attend a different class of yours for this week.) [This is a \\
& hypothetical example, as none of the participants used this \\
& downgrader in the present study.] \\
\hline
\end{tabular}

a As noted in Flöck (2016), the use of the past tense marker in bold here serves as a distancing device.

As done by Blum-Kulka et al. (1989), past tense forms were coded in this study as downgraders only if they are used with present time reference and can therefore be substituted by present tense forms without changing the semantic meaning of the utterance. When we apply this to the specific example here, it is substituted by 'Bi imzanızl alacağım ama...' = 'I'll get a signature of yours, but...', where the semantic meaning of requesting the signature at that present moment of speaking with the Turkish equivalent of 'WILL for immediate intentions' (Will, n.d.) is not changed.

b Preparatory request strategies of the form '...-bilir misiniz? /...-bilir miyim? = can you - could you - will you...? / can I - could I...?' were not treated as syntactic downgraders and therefore not included in this category as the interrogative in such cases is unmarked (Blum-Kulka et al., 1989; Economidou-Kogetsidis, 2013).

c The 'but' or suffixes like 'de, da' here seem to be used as a conjunction with the function of 'so' to link the cause clause to an effect clause. As Norrick (2009, p. 322) puts it, none is final; instead, they are followed by a pause that could be filled by an interlocutor with a new turn. They are meant to function as an 'unstated upshot' (Raymond, 2004) enabling the speaker to anticipate some kind of response (Beck, 2015).

\section{Copyrights}

Copyright for this article is retained by the author(s), with first publication rights granted to the Journal.

This is an open-access article distributed under the terms and conditions of the Creative Commons Attribution license (CC BY-NC-ND) (http://creativecommons.org/licenses/by-nc-nd/4.0/). 